\title{
Observation Claims and Epistemic Confidence in Aristotle's Biology
}

Daryn Lehoux, Queen's University

\begin{abstract}
This essay looks at the ways in which Aristotle signals his confidence in observation claims in his biological works. Widely seen as an astute observer of the natural world, Aristotle in fact makes surprisingly few explicit claims to personal observation, even if circumstantial and other evidence often provides strong hints of his own involvement. At the same time, because of the incredible variety (and often the localization) of biological species, Aristotle also necessarily relies heavily on the testimony of others. This essay shows how Aristotle employs careful rhetorical strategies to signal or qualify his certainty both in his own observations and in the reports of others, on a case-by-case basis, for his reader.
\end{abstract}

\begin{abstract}
A ristotle is widely recognized as a painstakingly careful observer of the natural world. ${ }^{1}$ However, for all that Aristotle's own care is frequently commented upon, we have no systematic picture of how he deploys and qualifies observation statements - his own or other people's - in the biological corpus, nor of how he signals his own certainty or uncertainty about individual claims. ${ }^{2}$ What we will see is that Aristotle adopts a number of rhetorical strategies for presenting
\end{abstract}

Daryn Lehoux is Professor of Classics and Philosophy at Queen's University. He is the author of Creatures Born of Mud and Slime (Johns Hopkins, 2017), What Did the Romans Know? (Chicago, 2012), and Astronomy, Weather, and Calendars in the Ancient World (Cambridge, 2007), as well as the coeditor (with Andrew Morrison and Allison Sharrock) of Lucretius: Poetry, Philosophy, Science (Oxford, 2013). Departments of Classics and Philosophy, Queen's University, Watson Hall 505, Kingston, Ontario K7L 3N6, Canada; lehoux@queensu.ca.

A version of this essay will appear as a chapter in Daryn Lehoux, Creatures Born of Mud and Slime: The Wonder and Complexity of Spontaneous Generation (Johns Hopkins, 2017).

Acknowledgments. I would like to thank Larry Principe, Stephen Menn, James P. Pitts, Laura Bevilacqua, H. Floris Cohen, and the anonymous referees for Isis for help with this material. The research was funded by the Social Sciences and Humanities Council of Canada and the Charles Singleton Center for the Study of Premodern Europe at Johns Hopkins University.

${ }^{1}$ See, e.g., Armand M. Leroi, The Lagoon (New York: Bloomsbory, 2014); Geoffrey E. R. Lloyd, Aristotelian Explorations (Cambridge: Cambridge Univ. Press, 1996), Ch. 5; Lloyd, Magic, Reason, and Experience (Cambridge: Cambridge Univ. Press, 1979), esp. p. 200 ff.; Wolfgang Kullmann, "Aristoteles' wissenschaftliche Methode in seinen zoologischen Schriften," in Geschichte der Mathematik und der Naturwissentschaften in der Antike, Vol. 1: Biologie, ed. Georg Wöhrle (Reihen: Steiner, 1999), pp. 104107; Kullmann, Wissenschaft und Methode (Berlin: De Gruyter, 1974); Hellmut Flashar, "Aristoteles," in Die Philosophie der Antike, Vol. 3, ed. Flashar (Basel: Schwabe, 1983), pp. 403-404, 410-411; Jean-Marie Le Blond, Logique et méthode chez Aristote (Paris: Vrin, 1973); and Louis Bourgey, Observation et expérience chez Aristote (Paris: Vrin, 1955).

${ }^{2}$ Lloyd, Magic, Reason, and Experience, Ch. 3, makes a good start. The topic is also handled as part of a larger look at Aristotle's methodology in Kullmann, "Aristoteles' wissenschaftliche Methode in seinen zoologischen Schriften." I readily recognize that my use of the term "biology" and its derivatives could be construed as anachronistic. Aristotle's project was not, of course, the same as that of any modern biologist. Priorities, starting assumptions, methods, aims, contexts, criteria - all of these differed

Isis, volume 108, number 2. (C) 2017 by The History of Science Society.

All rights reserved. 0021-1753/2017/0108-0001\$10.00. 
observation claims and that the ways in which he does so carefully (and consistently) qualify for his reader the strength of his confidence in the various claims. This question of Aristotle's confidence, it should be noted, is different from asking about the quality or accuracy of Aristotle's observations ${ }^{3}$ and instead draws attention to how he reflects on possibilities when things are ambiguous, how he signals his own doubts, hesitations, and qualifications about - or, alternatively, how he shows his confidence in - individual observation claims.

Aristotle's biology, it bears saying, relies heavily on observation claims about how one animal or another functions, how it moves, how it is constructed, how it compares to other animals, and much more. Of course, ancient physics, alchemy, astronomy, and any number of other scientific subjects also rely on observation; but what makes ancient biology different from these other subjects is the degree to which its observations come from third-party sources, as well as the degree to which it is what we might call a science of special cases. What I mean by this is that there are considerably more species of animals or plants than there are kinds of stars in antiquity or kinds of physical matter. ${ }^{4}$ Heavy objects behave the same way in Athens as they do in Alexandria; a cup of drinking water has, for all intents and purposes, the same properties on land as it does on board a ship. Earth falls, fire goes up, and magnets attract; these happen always and everywhere. But in biology, the deer outside of Athens may be significantly different from the deer outside of Alexandria, which may be significantly different again from whatever corresponds to a deer in the mountains of India. There are a very wide range of animals here and in other parts of the world that need explaining, no matter how strange or unique they seem to be-elephants, hyenas, and who knows what else-and for many of these Aristotle is going to have to rely on observations taken by people other than himself. True, ancient astronomers and other writers on the natural world rely heavily on observation reports from others, but an eclipse observed by someone in Babylon five hundred years ago is still fundamentally

to one extent or another, and there is a potential (but, I would argue, not inescapable) historiographic danger in the use of the modern term to describe the very different ancient practices. At the same time, Aristotle did not have a term or phrase to distinguish his work on animals and on life from the rest of his corpus, and so any word I choose to designate this collection is going to be an imposition or a projection onto Aristotle's own conceptions and priorities. Modern scholars have adopted various strategies to deal with versions of this problem, from G. E. R. Lloyd's "inquiry concerning nature" (which is too broad for my purposes and for the most part applies to an earlier period) to Andrew Cunningham's "natural philosophy" (at the same time both too broad and no less anachronistic in this context than "biology" might be taken to be). I take Lloyd's and Cunningham's critiques of earlier, sloppy uses of terms like "ancient science" and "ancient biology" as read and understood, and I use "biology" and its derivatives - in full recognition of Lloyd's and Cunningham's insights - as a simple shorthand to demarcate Aristotle's “work-on-animals-and-on-life." I beg the reader's indulgence to understand it in that way. That Aristotle did not explicitly refer to the subset of his work that I will be so discussing either as a single subset or with any single name need not cause alarm, so long as his work is handled sensitively with respect to its own priorities and with a keen awareness that it is not, and was never trying to be, modern biology. For the issues at play here see Geoffrey E. R. Lloyd, Early Greek Science (New York: Random House, 1970); Lloyd, Magic, Reason, and Experience (both of these works in any case use terms like "science" liberally and without egregious anachronism); Andrew Cunningham, "Getting the Game Right," Studies in History and Philosophy of Science, Part A, 1988, 19:365-389; Cunningham, "How the Principia Got Its Name,” History of Science, 1991, 29:377-392; Cunningham, "The Identity of Natural Philosophy," Early Science and Medicine, 2000, 5:259-278; Roger French and Cunningham, Before Science (Aldershot: Scholar, 1996); Cunningham and Perry Williams, "De-centring the "Big Picture," British Journal for the History of Science, 1993, 26:407-432; and H. Floris Cohen, How Modern Science Came into the World (Amsterdam: Amsterdam Univ. Press, 2010).

${ }^{3}$ There are moments when the modern reader is impressed by the care Aristotle takes to clarify or specify a distinction, but it goes without saying that such a response is inevitably grounded in a modern perspective on the ancient text rather than necessarily reflecting the priorities of Aristotle himself.

${ }^{4}$ Perhaps the study of chemicals, of rocks, metals, and minerals, or even of medicine might be seen as "sciences of special cases" in a similar way to what I am claiming for Aristotle's biological investigations, but Aristotle does not engage these to anything like the same extent as he does animal species. My point here is to contrast the problems faced by Aristotelian biology with those faced by his approach to physics, for example. 
an eclipse, and the possibilities for variation are comparatively limited. A goat observed at Babylon, on the other hand, may have features and properties entirely unheard of in Macedonian goats. Animals at sea are entirely different from those on land (except when they are not, of course). One could go on. In short, the raw data of Aristotle's biology is significantly more complex, much messier, and frequently more local than the raw data in other parts of his corpus. We should look, then, at precisely how Aristotle handles that data, his observation claims.

Combing through Aristotle's biological corpus for observation reports, for words and phrases denoting things that "have been seen" at some point or "were observed" on particular occasions, as well as phrases denoting testimony ("they say," "it is said that," "so-and-so says"), we find that observation claims in Aristotle fall under three broad epistemological headings: things he believes to have been accurately observed (sometimes clearly by himself, sometimes clearly by others, sometimes not clearly ascribed), things he believes to have been poorly observed or gullibly reported (always by others), and observations (by himself or others) for which he wishes to qualify his certainty in one way or another. In this last case, he qualifies his claims using three primary rhetorical strategies: telling us that an observation has been reported by someone else (leaving the reader to judge its plausibility), telling us that an observation is or was "difficult" to make or otherwise uncertain, or telling us that an observation seems secure, insofar as no counterinstances have yet been observed (implicitly carving out a space for the possibility that the evidence may one day change - and, with it, our theories about the animals or processes involved).

\section{SIMPLE FACTICITY}

Aristotle's general practice in reporting an observation is simply to put that observation in the passive voice: "it has been seen that...," most often in the Greek perfect tense ( $\tilde{\omega} \pi \tau \alpha$, for example) or else in the aorist tense ( $\ddot{\varphi} \theta \eta$, for example). Modern scholars have often taken many of these reports to be Aristotle's own observations. ${ }^{5}$ It is certainly possible, and often quite tempting, to think that they are his own, although there are also instances where it appears probable that Aristotle may not himself be the original observer, either because the observations in question are well attested in earlier authors (Herodotus is a favorite) or because it is implausible that Aristotle himself could have made the observations in question. But if we cannot always be certain that Aristotle himself made some specific observation that he reports, one thing we can tease out from many of his observation statements is that, for his own part, Aristotle has confidence in their veracity; and this is significant for how he uses those observations.

In some instances, although perhaps fewer than modern readers may wish for, Aristotle seems to tell us explicitly that he has personally made a particular observation. So, for example,

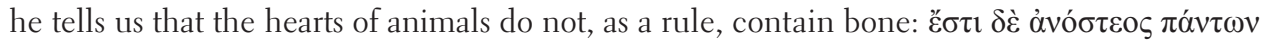

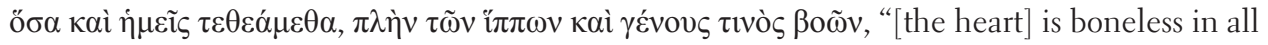
animals that we ourselves have observed, except in horses and one kind of cattle." Here the claim to autopsy is both clear and emphatic. Greek does not normally need to deploy personal pronouns as grammatical subjects ("I" and "we," for example), since the doer of an action is already signaled in the verbal ending (- $\alpha \mu \varepsilon \theta \alpha$ in this case). When an author does so, it is because he wants to emphasize his own or another actor's involvement a little more strongly than the

\footnotetext{
${ }^{5}$ Leroi, Lagoon (cit. n. 1), for example, thinks that the level of detail in many of the anatomical observations shows that Aristotle himself must have done the dissections on "about 35" different species (p. 59). Still, the level of detail is no guarantee that any given anatomy was Aristotle's own work, even if we do know that he did a great deal of such work generally.

${ }^{6}$ De partibus animalium 666b17-19. (Here and throughout this essay, translations into English are mine unless otherwise indicated.)
} 
more common wording would offer (hence my use of the reflexive "we ourselves"). Aristotle leaves little room for doubt here. But at the same time, he is subtly qualifying his knowledge claim, as we will see him often do in later examples, by pointing out that the experiential basis to which the claim is being pegged is inherently limited: the phrase "in all animals that we ourselves have observed" clearly leaves open for the reader the possibility that there are animals still out there-perhaps not native to Greece, or at any rate ones not yet brought to Aristotle for dissection - that also have bones in their hearts. He is saying: there are at least these two exceptions to the general rule about hearts, but there may of course be more.

More confident is a passage in the Generation of Animals where Aristotle rules out the theory that in cases of multiple births males are formed in one part of the womb and females in another:

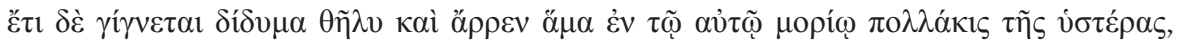

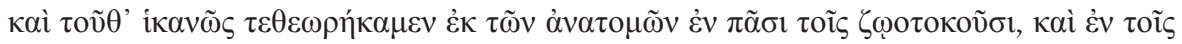

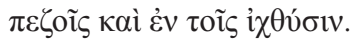

Moreover, both male and female twins are formed at the same time in the same part of the womb often, and we have observed this sufficiently in dissections of all the vivipara, in both land animals and fish. ${ }^{7}$

Here Aristotle shows no doubt whatsoever about his conclusion, drawn from what he implies is a rich store of observation, in "all the vivipara," and the evidence that he has collected is, he tells us explicitly, "sufficient" in quantity and quality to make the case. ${ }^{8}$ In contrast to the

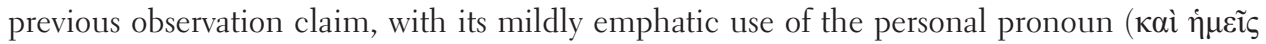
$\tau \varepsilon \theta \varepsilon \alpha \dot{\alpha} \mu \varepsilon \theta \alpha$ ), in this instance Aristotle uses the simpler and more common wording that leaves the pronoun unstated ( $\tau \varepsilon \theta \varepsilon \omega \rho \eta ์ \kappa \alpha \mu \varepsilon v)$, while still laying explicit claim to personal observation.

Elsewhere we see apparent claims to autopsy, though with perhaps less confidence in his conclusions, when he asserts that, of all the organs in the fetus, the heart is formed first. He

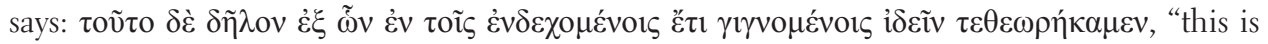
clear from all [the cases] we have seen where it is possible to see them coming to be." Again we see his use of the first-person-plural verb, but it is conjoined with a frank admission that in some, or even many, cases there are difficulties of observation that may make certainty elusive.

Beyond these, there are not a great number of instances in the biological corpus where Aristotle seems to be pointing explicitly to observations that he himself has made, although there are a host of observations that most commentators are happy to ascribe to him without his explicit confirmation (and, indeed, I largely follow them). In some of these cases, the evidence is reasonably strong and direct that he himself was the observer, but in others the conclusion is admittedly less definite. One such instance we find in a long passage beginning at Historia animalium 51lbll, where he criticizes in great detail the writings of his predecessors Syennesis of Cyprus, Diogenes of Apollonia, and Polybus (said in some sources to be the son-in-law of Hippocrates) on the anatomy of the blood vessels. He opens his criticism as follows:

\footnotetext{
${ }^{7}$ De generatione animalium 764a33-36. This observation is adduced not so much for its own sake as for how it bears on Aristotle's critique of Empedocles and on his own larger theory of sex determination.

${ }^{8}$ This and some of Aristotle's other rhetorical qualifications are noted, albeit briefly, by Le Blond, Logique et méthode chez Aristote (cit. n. 1), p. 246.

${ }^{9}$ De iuventute et senectute 468b29-30. See also Lloyd, Magic, Reason, and Experience (cit. n. 1), p. 216, for commentary and further context.
} 


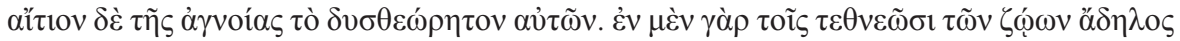

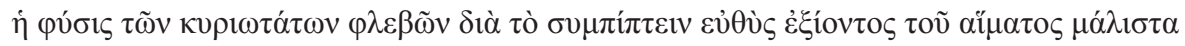

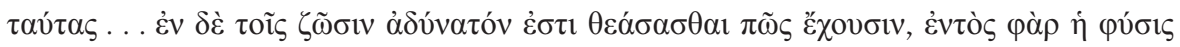
$\alpha \hat{\tau} \tau \tilde{\omega} v$.

The cause of their ignorance is the difficulty of observing [the blood vessels]. In animals that are dead, the nature of the most important vessels is unclear because these collapse completely as soon as the blood leaves them . . . and in the living it is impossible to observe how they are situated because their position is internal. ${ }^{10}$

He then quotes long passages from each author, ${ }^{11}$ summarizes the ideas of a few unnamed others, and dismisses them all on the grounds that they are collectively mistaken in their view that the source of the blood vessels is ultimately in the head.

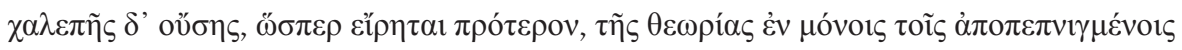

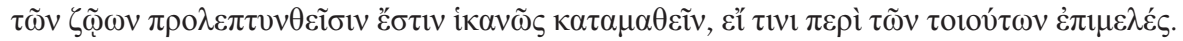

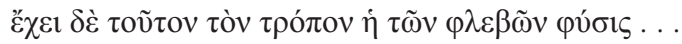

Observation being, as I said before, difficult, it is only in those animals that have been strangled that it is possible to learn sufficiently, if one is concerned about such things.

And the nature of the blood vessels is as follows ...12

At this point Aristotle gives a long, careful, and detailed description of the layout of the blood vessels in animals. He discusses their positions and sizes as though for a generic animal, occasionally adding more specific remarks on the differences between some particular feature or other in small animals versus large, or between males and females, or in quadrupeds versus birds versus fish. Since Aristotle has earlier dismissed his predecessors' accounts and cautioned his reader about the proper way to kill animals for dissection, it is a natural conclusion that his description of the blood vessels is rooted in his own careful observation, even if he does not say it in so many words. And since he discusses distinctions between different kinds of animals and offers advice about which are best for observation, one also gets the impression that his experience in this kind of dissection is extensive, an impression further confirmed by his tantalizingly common references to a sadly long-lost work of his called The Anatomies. ${ }^{13}$

Other passages also occasionally establish facticity by hinting strongly at the author's personal experience. Take, for example, his discussion of the general anatomy of the animal heart:

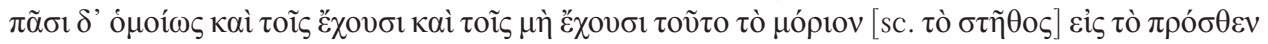

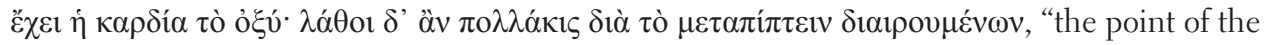
heart is toward the front in all animals, both those that have [a chest] and those that do not, but

\footnotetext{
${ }^{10}$ Historia animalium 511b13-20.

${ }^{11}$ The Polybus passage that he quotes happens to correspond with parts of the Hippocratic texts On the Nature of Man and On the Nature of Bones.

${ }^{12}$ Historia animalium 513al2-16.

${ }^{13}$ On this work and its possible format see James G. Lennox, "Aristotle's Biology," in The Stanford Encyclopedia of Philosophy, Spring 2014 ed., https://plato.stanford.edu/archives/spr2014/entries/aristotle-biology/; Jonathan Barnes, Aristotle’s Posterior Analytics (Oxford: Oxford Univ. Press, 1975), p. 240; and William David Ross, Parva naturalia (Oxford: Oxford Univ. Press, 1955), p. 264.
} 
this can often escape one's notice because of a change during dissection." ${ }^{14}$ Here the cautionary note for the reader about the care needed to make the observation correctly would seem to be sounding a clear note of personal experience on Aristotle's part. In any case, even if he is not quite explicit about personal autopsy, we at least glean from the passage that he is setting out the observation for his reader without doubt or hesitation.

The series of detailed observations with which he describes the development of the chick in its egg at Historia animalium 561a4-562a22 are also widely taken to be his own, although as usual all that he offers is a clinical description of the parts and the order of their emergence, with an occasional interjection that this or that feature becomes "clear" ( $\delta \tilde{\eta} \lambda \mathrm{o} \varsigma$, $\varphi \alpha v \varepsilon \rho o ́ s)$ or

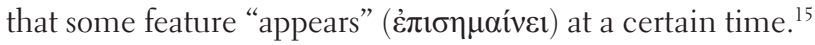

One observation that Aristotle reports with full certainty and that sounds like it may well be his own has caused some consternation among later commentators, as it is entirely unclear what Aristotle thinks that he or his source was seeing:

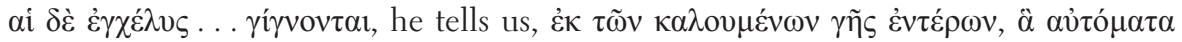

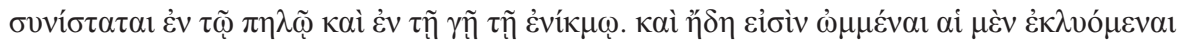

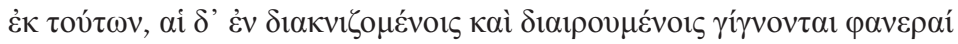

Eels ... are born from the so-called earth-worms [lit.: earth's guts] which spring up spontaneously in clay and in damp earth. [Eels] have now been seen emerging from these, and they become visible when [the worms] are cut open and dissected. ${ }^{16}$

This observation, reported with perfect confidence by Aristotle, is for him a key piece of the evidence that eels are spontaneously rather than sexually generated. Nevertheless, given the fact that no part of the difficult-to-observe reproductive cycle of the eel involves anything worm-like happening on shore, it is hard to know what the actual observation might have been in this instance. That said, we note that Aristotle presents the observation as though it were entirely unproblematic, whatever it may have been.

It is on the basis of confident passages such as these that scholars have come to believe that Aristotle himself made many, if not most, of the dissections and many of the other observations described in his biological corpus. I agree that the conclusion is often more than tempting; but, of course, he generally does not claim personal autopsy explicitly, and caution may be called for on a case-by-case basis. What is abundantly clear from such passages, however-and this is for our purposes the more important point-is that Aristotle is signaling his complete confidence in these observations. For him, these are unproblematic facts, put to the reader simply, straightforwardly, and without reservation.

In other instances Aristotle shows every sign of confidence in an observation that he reports, but for various reasons the reader may well suspect that he is repeating testimony given to him rather than reporting on his own experience. When he discusses multiple births in humans, for

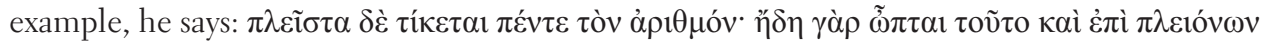

\footnotetext{
${ }^{14}$ Aristotle, Historia animalium 496a9 ff.; cf. 508a32. See Kullmann, "Aristoteles' wissenschaftliche Methode in seinen zoologischen Schriften" (cit. n. 1).

${ }^{15}$ Compare also the "sufficiently observed" proof that wind eggs (by which he means unfertilized eggs; cf. Historia animalium 751b22) are not produced by the delayed action of male seed from earlier matings at De generatione animalium 75 lal3. They are instead something produced by the female all by herself. See also Kullmann, “Aristoteles' wissenschaftliche Methode in seinen zoologischen Schriften," p. 107. Compare also the description of the chick's development in the Hippocratic On the Nature of the Child, 29.

${ }^{16}$ Historia animalium 570a3, 16-19; cf. 538a4.
} 


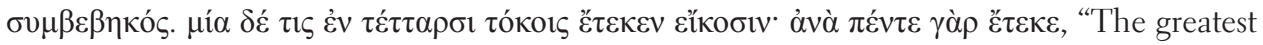
in number born is five. And this event has by now been seen on rather a number of occasions. One woman gave birth to twenty children in four births, for she birthed in fives." ${ }^{17}$ Now, it is possible that this woman's four multiple births constitute the entirety of the "number of occasions" (غ̇ $\pi \grave{i} \pi \lambda \varepsilon$ เó $\omega \omega v)$ that Aristotle says back him up, but to my ear the Greek sounds a little more generous than this (that kaì helps). I suspect Aristotle had other reports in mind, meaning that, given the rarity of quintuplets, his $\tilde{\omega} \pi \tau \alpha$, "it has been seen," likely includes testimonial evidence (and, indeed, there is no guarantee that Aristotle himself had actually even seen the one very fecund woman he describes).

Similar hints that testimony may lie behind a given observation claim litter the corpus. For example: $\pi \circ \lambda \lambda \alpha \chi 0 \tilde{v} \tau \varepsilon \theta \varepsilon \omega \rho \tilde{\eta} \sigma \theta \alpha$, "it has been observed," he says, "in many places" that hedgehogs move the entrances to their burrows in response to changes in wind direction. ${ }^{18}$ It certainly sounds like Aristotle is alluding to other observers here besides himself. Even clearer is an observation he records about hyenas. The hyena, he says, "is seen," $\tilde{\omega} \pi \tau \alpha 1$, to have only

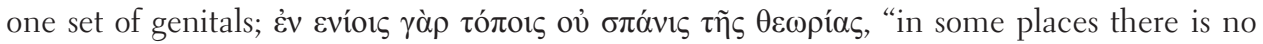
shortage of this observation." ${ }^{\prime 19}$ Here again, Aristotle sounds like he is alluding to observations made by others, and his "in some places" is more plausibly taken as referring to foreign locales than to private collections he may have visited personally. Nevertheless, it is clear from the references to ubiquity that he wants his reader to read these reports from elsewhere as straightforwardly factual.

\section{TESTIMONY (QUALIFIED)}

Often, though, Aristotle is very clear about where he has taken his testimonial observations from, and he uses phrases that mark out the observer explicitly as someone other than himself, which often at the same time serves implicitly to qualify his certainty. In many instances he is more or less vague about who, precisely, these other observers are, using a bald "they say," pó бov, while at other times he is a little more specific: "fishermen say," or "shepherds say."

Instances of the simple use of "they say" in the biological corpus include stories that Ar-

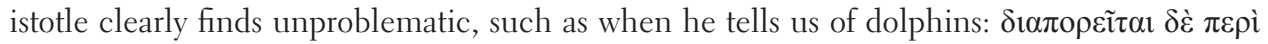

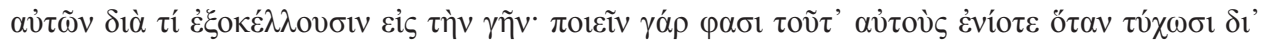

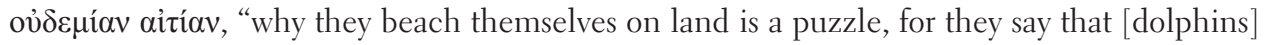
sometimes do this whenever they may happen to for no reason." ${ }^{.20}$ What we can see is that he thinks the fact itself to be fairly straightforward, setting it out as a known puzzle about the species, while at the same time distancing himself from any potentially literal reading of "for no reason," insofar as he implies that there must be some reason for the behavior if the question is in fact to be a puzzle.

In other instances it is less clear whether Aristotle believes in what "they say," as when he tells us that people say that salamanders put out fires by crawling through them or when he reports that "they say" that a certain Syracusan drunkard used to bury fresh eggs under his blanket and not stop drinking until they hatched. ${ }^{21}$ Other facts that he so attributes to some unnamed "them" include that the phykis is the only fish to build nests and that elephant handlers

\footnotetext{
${ }^{17}$ Historia animalium $584 \mathrm{~b} 33 \mathrm{ff}$.

${ }^{18}$ Historia animalium 612b4.

${ }^{19}$ De generatione animalium 757a7. There were a number of different theories on hyena genitalia in antiquity, and Aristotle is here deploying the observation to counter those who believed hyenas each to have two sets of genitalia, male and female.

${ }^{20}$ Historia animalium 631b3-4.

${ }^{21}$ Historia animalium 552b7, 559b4.
} 
give olive oil to elephants in order to expel any iron splinters they may have picked up. ${ }^{22}$ Elsewhere, Aristotle prefaces a story about elephants with "They say that in India . . ., ${ }^{23}$ reminding us that, as with the genitalia of hyenas, some facts or curiosities that Aristotle wants to record concern animals to which he simply has no access because of geographical distance. Similarly, we sometimes see him report facts from observers "in Libya," or "in Crete," or "around Lake Maeotis," to take a few examples. ${ }^{24}$ Finally, Aristotle sometimes flags his certainty or uncertainty regarding testimonial observations more explicitly, by using phrases like "it has been observed often" or, at the other end of the spectrum, "some people say."

We can also see him sometimes accepting part of a story that "they say" but rejecting another part (possibly reported by a different "they"). Thus, when Aristotle tells us that "some [fish] are

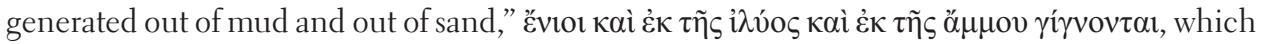
he reports as an unproblematic fact, the evidence he offers is testimonial:

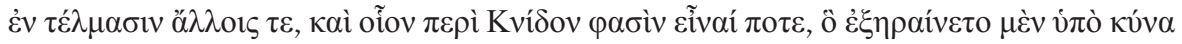

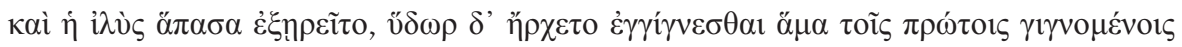

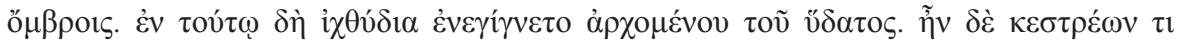

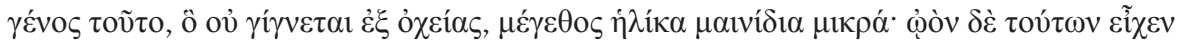

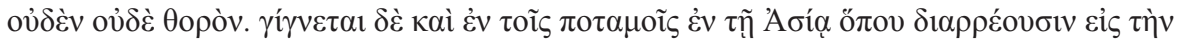

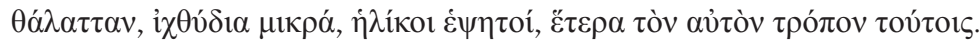

[This happens] in different ponds, and they say one near Cnidus is sometimes like this. It dried up at the time of the dog star and all the mud hardened. But then water came when the first rains arrived. Little fish appeared in it as soon as the water started, and this was a species of mullet which is not generated by mating. Its size was like a small sprat, and in them there was neither egg nor milt. Different small fish are generated in the same way as these in the rivers of Asia where they flow into the sea. ${ }^{25}$

Notice the little details that Aristotle throws in for verisimilitude: the time of year, the location, the size of the fish, and even the matter-of-fact-ness that the species is (already?) known not to be generated by mating. But above and beyond these, he includes one of his favorite and most convincing observations for proving the spontaneous generation of eels, repurposed here for our spontaneously generated mullets: none of them had eggs or milt. One gets the impression from how it is reported that Aristotle is almost looking over the shoulder of his source. Who this may have been is left unsaid, although it clearly must have been someone interested in exactly the question of how these fish were generated. Who else, after all, would care enough to notice all of these particular details? As he continues this discussion, however, Aristotle's tone shifts, for not everything that people say is equally reliable:

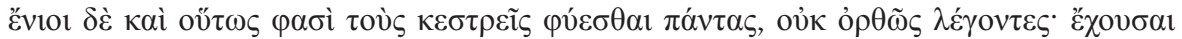

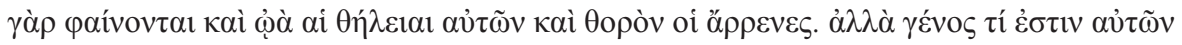

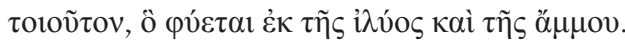

\footnotetext{
${ }^{22}$ Historia animalium 607b21, 605b4.

${ }^{23}$ Historia animalium $571 \mathrm{~b} 33$.

${ }^{24}$ For Libya see Historia animalium 606b10; for Crete see Historia animalium 612a3; for Lake Maeotis see Historia animalium 620b6, among other examples.

${ }^{25}$ Historia animalium 569 all ff.
} 
Some say that all mullets are generated in this way, but they say so incorrectly, for the females are observed with eggs and the males with milt. But there does exist a species of them like that, which is generated from mud and sand. ${ }^{26}$

In other instances Aristotle tells us who his sources are, but this information comes in tandem with what we might call a conditional appeal to authority. This occurs where Aristotle reports the testimony of professionals of one sort or another. So fishermen say that certain parasitic crabs come into existence with their hosts; women who hunt for drugs say that a certain medicinal substance is difficult to obtain from mares; shepherds say that wind direction has an effect on the sex of lambs; and beekeepers say - well, beekeepers say rather a lot of things. ${ }^{27}$ But we need to keep in mind that these appeals to professional lore are inherently conditional. On the one hand, the reader is faced with the important fact that professionals have an intimate knowledge of the tools and objects of their day-to-day labor and so will often be able to tell us something that we would not otherwise know about the animals with which they work. At the same time, the ancient reader would be acutely aware that these fishermen, shepherds, and women who collect medicines were almost certainly uneducated and illiterate-and so perhaps less than completely reliable on a number of fronts. (Do they understand the questions or their observations properly? Are they capable of reporting carefully or of noticing relevant potential counterevidence? Can they be trusted to tell the truth?) Indeed, Aristotle explicitly acknowledges the problem in a discussion of the mistaken belief that female fish swallow the milt of the male. He tells us that those who hold this view have failed to observe certain details

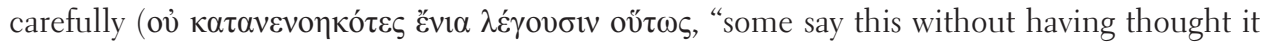

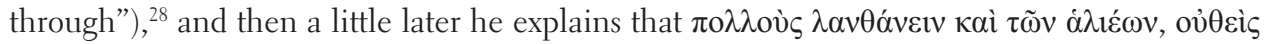

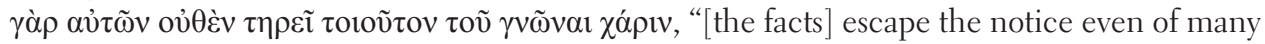
fishermen, for none of them observes [mating] for the sake of study." ${ }^{29}$ They may see it incidentally, but their observations are colored by the fact that they have no reason to look closely at the relevant details - or even perhaps to know what the relevant details might be. The problem

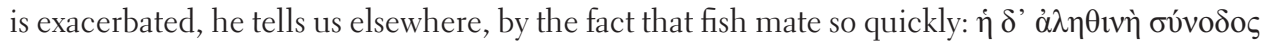

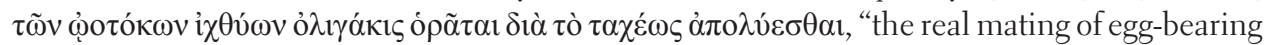
fish is seldom seen due to their speedy completion." "Still," he immediately reminds us, care will

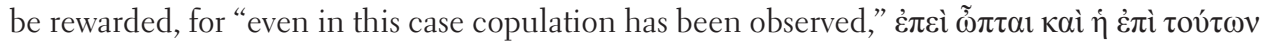
òzcía. ${ }^{30}$

Whether or not Aristotle believes in any individual claim with more or less certainty, we can see him clearly distancing this testimony from his own observation and experience by the use of formulas that attribute these observations unambiguously to others. The reader can see exactly where the evidence stands for these claims.

\footnotetext{
${ }^{26}$ Historia animalium $569 \mathrm{a} 22 \mathrm{ff}$.

${ }^{27}$ For the testimony of fishermen see Historia animalium 547b30; for that of drug makers see Historia animalium 572a22-28; for that of shepherds see De generatione animalium 767a8; for that of beekeepers see De generatione animalium 759b20-760a2, etc. ${ }^{28}$ De generatione animalium $756 \mathrm{a} 7$.

${ }^{29}$ De generatione animalium 756a32-33. See also Kullmann, "Aristoteles' wissenschaftliche Methode in seinen zoologischen Schriften” (cit. n. 1), p. 106 ff.; and Bourgey, Observation et expérience chez Aristote (cit. n. 1), p. 89.

${ }^{30}$ Historia animalium 54la32. Contrast this situation with that of sharks and rays, which take longer to mate: $\tau \dot{\alpha} \mu \grave{\varepsilon} v$ oũv $\sigma \varepsilon \lambda \alpha \dot{\chi} \eta$

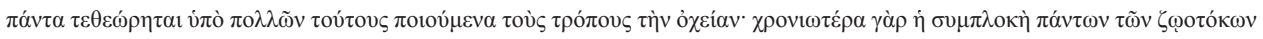

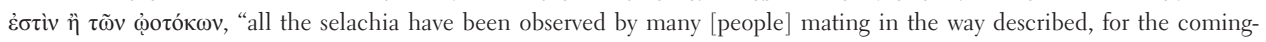
together of all vivipara takes longer than that of ovipara" (Historia animalium 540b20).
} 


\section{DEGREES OF UNCERTAINTY}

Having made the admission that sometimes people who work with animals for a living will miss important facts, however, Aristotle still frequently (and necessarily) relies on their expertise, although he often handles it with care. One particularly cautious deployment of professional knowledge occurs in contexts where Aristotle is himself unsure what to make of the evidence, as he tells us explicitly. Here the uncertainty stems from one of two sources: the evidence is rare, or the evidence is ambiguous. Two such instances occur in close proximity to each other and involve professional fishermen or sailors. ${ }^{31}$ In the first example, Aristotle's uncertainty arises from the rarity of the phenomena:

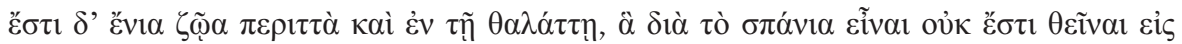

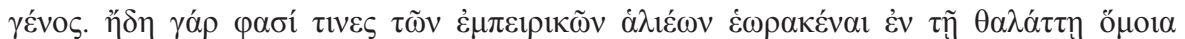

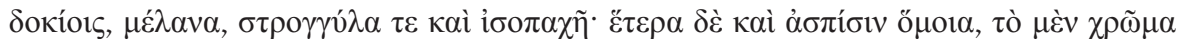

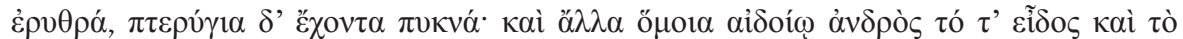

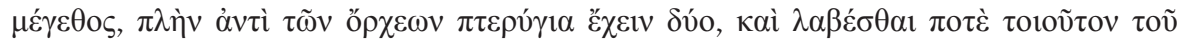

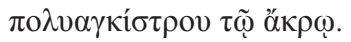

There are some strange animals in the sea which, because of their rarity, cannot be assigned to a genus. For instance, some experienced fishermen say that they have seen in the sea animals like planks, black, round, and of uniform thickness; others like shields, red in color, having many fins; and still others like a man's genitals in both size and shape, except that in place of testicles they have two fins, and [they say that] one was once caught on the hook of a longline. ${ }^{32}$

Here Aristotle makes it clear that he is not entirely sure what to make of these animals but not that he is unsure what to make of the truth-value of the claims that they were seen. Hints that he has more than a little confidence in the observations include the fact that he explicitly (and very unusually, for him) says that these reports come not just from fishermen but from experienced fishermen, $\dot{\varepsilon} \mu \pi \varepsilon \imath$ เ of the last class having once been caught, even lending verisimilitude by including the detail about the kind of line on which it was caught (perhaps he also thinks this tells him something about its diet). In other contexts he similarly flags his confidence in observation reports, as at Historia animalium 504b26, where, apropos of the suckling behavior of dolphins, he says кaì

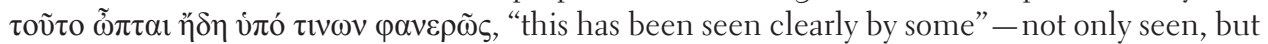
seen clearly, and by more than one authority.

At the other end of Aristotle's use of professional testimony are instances where he tells us that he is uncertain not about the source but instead about the evidence itself, regardless of what the professionals say. For example, in discussing the senses in the class of animals he calls testacea, both how many they may have and how good their perception might be, he says:

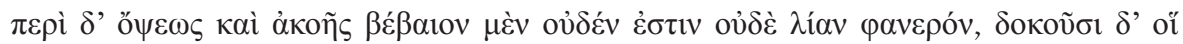

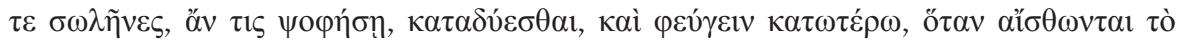

\footnotetext{
${ }^{31}$ The Greek word is $\dot{\alpha} \lambda \imath \tilde{\eta} \varsigma$, which means those who work on the sea. A literal translation would be "saltmen" or perhaps "salts," although the Greek term can include novice sailors in a way that the English "salts" generally does not. I will use "fishermen," since the majority of Aristotle's uses of the term seem to point to people who work with fish for a living, with the caveat that he may be referring to merchant or military sailors in some instances.

${ }^{32}$ Historia animalium 532b18-26. See also Kullmann, "Aristoteles' wissenschaftliche Methode in seinen zoologischen Schriften" (cit. n. 1), p. 107
} 


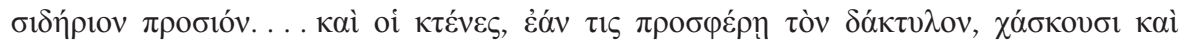

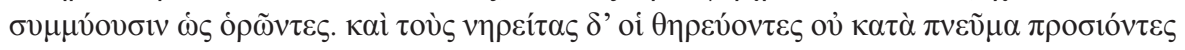

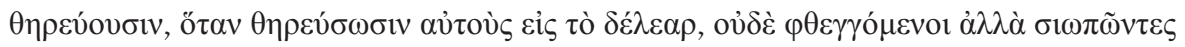

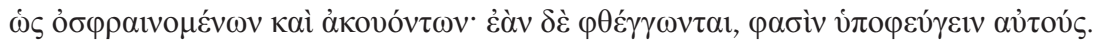

Concerning sight and hearing nothing is certain or very clear. When someone makes a noise, razor clams pull down and hide deeper as though they perceive the iron approaching. . . . And scallops, if someone brings a finger near them, open and close as though they saw it. ${ }^{33}$ Additionally, people hunting sea-snails never go upwind of them once they have lured them to the bait, nor do they talk but instead keep quiet, as though the snails can smell and hear. If they talk, they say that the snails will flee. ${ }^{34}$

The source of Aristotle's puzzlement in the face of this evidence is not entirely clear. Likely the apparent behavior of the animals is counterbalanced by those animals' seeming lack of the sensory organs that they would need in order to see or hear. In the last of the examples, which relies on the testimony of snail hunters, we may be faced with the problem we saw earlier of the inherent reliability of the uneducated. That this is a genuine concern for Aristotle is clear from another passage where he sets out his own knowledge of the octopus as superior to what the fishermen think they know:

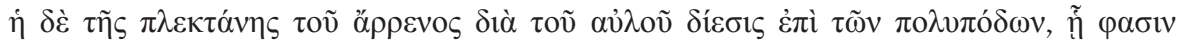

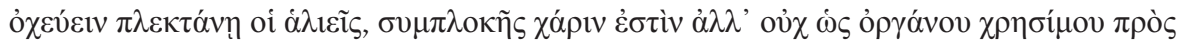

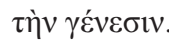

In octopus, the insertion of the male's tentacle into the funnel [of the female], by means of which tentacle fishermen say they mate, is [really] for the sake of embracing, and not an organ useful for generation. ${ }^{35}$

There are other passages where he worries about what professionals report and a great number of passages where reports or stories from unnamed persons, professional or otherwise, are dismissed outright. ${ }^{36}$ In one interesting passage, Aristotle pits one group of observers against another on one subject, only to tell us that they do, however, all agree on a second subject:

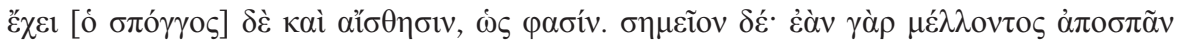

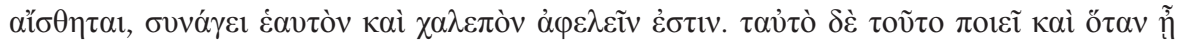

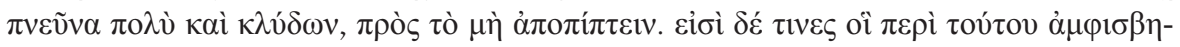

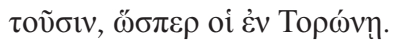

\footnotetext{
${ }^{33}$ Arthur Leslie Peck, Aristotle: History of Animals (Cambridge, Mass.: Harvard Univ. Press, 1970), p. 73, translates this passage as "scallops, if anyone puts his finger near them while they are open, at once close up," but this does a disservice to the Greek. I suspect that his trouble with making sense of the wording came from a simple unawareness that scallops in fact "swim" to escape predators by rapidly clapping their shells open and closed to effect a kind of biological jet propulsion.

${ }^{34}$ Historia animalium 535al3-22.

${ }^{35}$ De generatione animalium 720b32-35. Interestingly, Aristotle elsewhere seems less certain of how this tentacle is used. See Historia animalium 524a5, 541b9, and 544a8, signaling, as most scholars think, a development in his thinking over time rather than a later intrusion into his text by other hands. See also Kullmann, "Aristoteles' wissenschaftliche Methode in seinen zoologischen Schriften" (cit. n. 1), p. 107.

${ }^{36}$ See Lloyd, Magic, Reason, and Experience (cit. n. 1), p. 212; and Lloyd, Aristotelian Explorations (cit. n. 1), p. 75.
} 
[The sponge] has perception, so they say. The indication [of this] is that it perceives when someone is going to harvest it, contracts, and becomes difficult to remove. It also does this whenever there is a lot of wind or rough water so that it doesn't get detached. But there are some who dispute this, such as those in Torone. ${ }^{37}$

One gets the impression that Aristotle is happy to allow sponges to have some level of sensation, although he is in the end noncommittal, telling us only what he knows from the various reports. What everyone agrees on, though - and he makes the point quite forcefully - is that

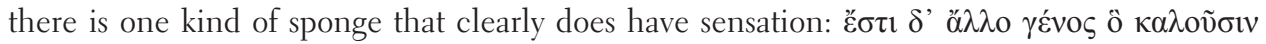

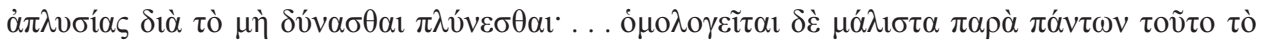

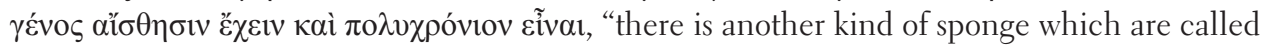
'dirty sponges' because they cannot be washed . . . it is completely agreed by everyone that this kind has perception and is long-lived." 38 Aristotle could hardly be more emphatic here. It is agreed; it is agreed completely; and it is agreed completely by everyone.

\section{NEGATIVE OBSERVATIONS}

The last class of observation statements in Aristotle consists of what we might call "negative observations," and these pose their own special epistemological problems. By "negative observations," I refer to moments where Aristotle tells us that some (perhaps otherwise-common) behavior or feature has never been observed in a particular group of animals. As with his positive observation claims, where Aristotle commonly signals to the reader his degree of confidence in individual observations, he is likewise quick to qualify his certainty with regard to negative statements. Qualifications can range from the confident-but-still-cautious "this has never been observed" to the frank admission that "sufficient observations have not yet been made."

Even when he clearly thinks that a "never-been-seen" phenomenon implies categorical nonexistence, he is surely aware that these assertions are not, strictly speaking, logically binding. Nevertheless, he often finds them very convincing. So in the Historia animalium, in discussing the generation of eels, he tells us, without any hint of doubt, that $\alpha i$ $\delta \dot{\varepsilon} \dot{\varepsilon} \gamma \chi \varepsilon \dot{\varepsilon} \lambda \nu \varsigma$ oü $\tau^{\prime}$

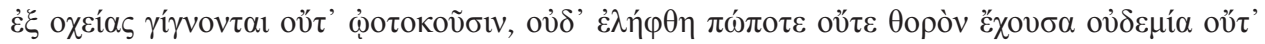
ஸ̣á, "eels are not generated by mating, nor do they bear eggs, and none has ever been found having any milt or eggs." 39 The conclusion that eels do not generate by mating comes across as a statement of fact, based in part on the negative observation that they have never, ever, been found with milt. Similarly, in trying to work out how bees are generated, Aristotle shows full confidence in the conclusions that among worker bees there cannot be both males and females and that, of workers and drones, they are not one of them male and the other female. His primary proof of these points is that if either of the two were the case, then someone should have seen bees mating by now, but no one has:

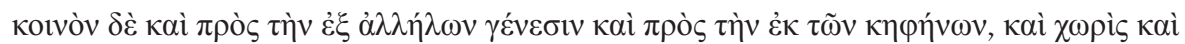

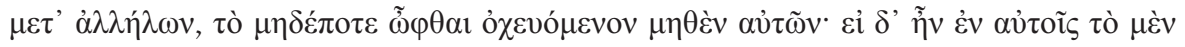

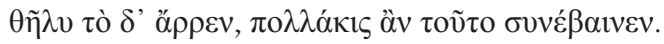

The common argument against both the theory of generation by workers mating with each other, and that of generation from drones (either mating with other drones or with

\footnotetext{
${ }^{37}$ Historia animalium $548 \mathrm{~b} 11 \mathrm{ff}$.

${ }^{38}$ Historia animalium $549 \mathrm{a} 4 \mathrm{ff}$.

${ }^{39}$ Historia animalium $570 \mathrm{a} 3$; cf. $538 \mathrm{a} 8$.
} 
the workers), is that none of them has ever been seen mating. And if there were both male and female among them, this would happen often. ${ }^{40}$

Again, "not ever seen" (sufficient opportunity implied) seems here to be proof enough of "not ever happening." (I shall have more to say on bees presently.)

A weaker version of this sort of negative observation modifies the "not ever" formula (où

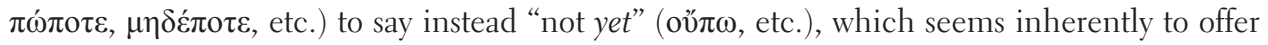
at least a little more in the way of an admission that our understanding may one day change if more evidence comes to light. A lovely example comes in Aristotle's discussion of whether there are any animal species that have only females and no males:

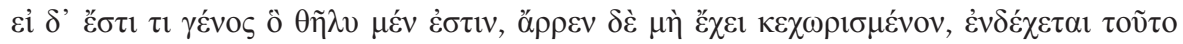

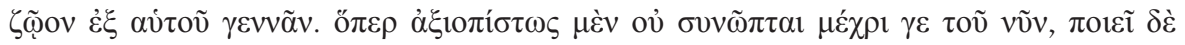

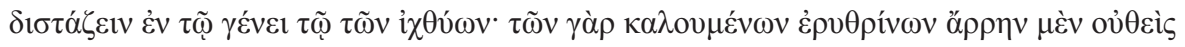

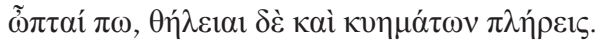

If there is a species which is [entirely] female and has no distinct male, it may be possible for this animal to generate from itself. This has not been reliably observed thus far, at any rate, but there is [an example] among fish that gives us pause, for in the so-called erythrinoi, no male has yet been observed, and the females are full of eggs. ${ }^{41}$

Aristotle is being both admirably clear and admirably careful. He readily admits that nothing is certain, since sufficient observations have not yet been made to cinch the case. However-and here things get very interesting - he says that one species of fish in particular, the erythrinus, has been observed enough that he is willing to entertain the real possibility that it is all-female and that it reproduces parthenogenetically. But he does not go so far as to say that the matter is definite. Quite the contrary: just after saying this he repeats his statement that the proof is not

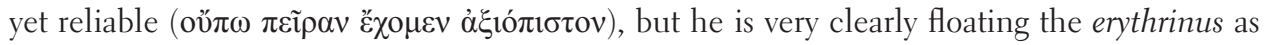
the best contender of which he is aware for a species with only one sex. Indeed, the erythrinus is one of Aristotle's go-to species when he wants to point to animals that are an exception to the otherwise-standard patterns of sex differentiation and reproduction, and elsewhere he has no

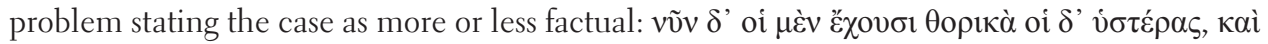

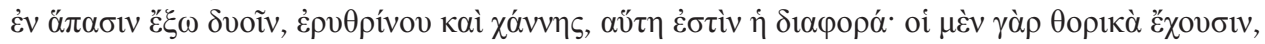

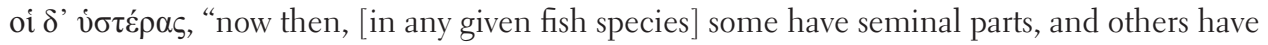
wombs, and [this is the case] in all but two: the erythrinus and the channa, and this is the difference: the one has seminal parts and the other wombs." ${ }^{2}$

\footnotetext{
${ }^{40}$ De generatione animalium 759b20-23. Compare Pliny, Naturalis Historia 11.46: apium enim coitus visus est numquam, "the mating of bees has never been observed."

${ }^{41}$ De generatione animalium 74la33-37.

${ }^{42}$ De generatione animalium 755b20-22. I take the last clause to involve a reversal of the usual order of reference in a $\mu \varepsilon \dot{v} . . . \delta \varepsilon$ construction - on which see John D. Denniston, The Greek Particles, 2nd ed. (Oxford: Clarendon, 1954) - although this does not solve the main problem with the clause, which is that it is incompatible with a passage elsewhere, where Aristotle seems to suggest that channae, like erythrinoi, are only ever full of eggs (Historia animalium 538a21). There are, however some textual issues with the latter half of the sentence (from $\alpha$ $\tau \eta$ onward) that may account for the problem. Whether or not textual corruption does explain the surprising invocation of "seminal parts" here, the important thing for our purposes is the statement of fact in the first half of the sentence. On an unrelated note, Peck, in Aristotle: History of Animals (cit. n. 33), Vol. 2, p. 93 n a, commenting on Historia animalium 567a27, credits Aristotle with the discovery that some species of sea perch (which most commentators reckon both the erythrinus and the channa to be) are hermaphroditic. But neither the passage in question nor any other that I can find in Aristotle calls them hermaphroditic, and so far as I know the fact was not discovered until the late eighteenth century.
} 
A very similar case occurs in a discussion of another fish, the rhinobatos, which he thinks may well be an animal hybrid:

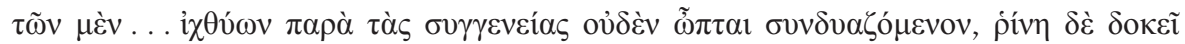

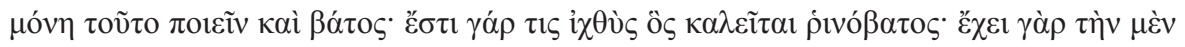

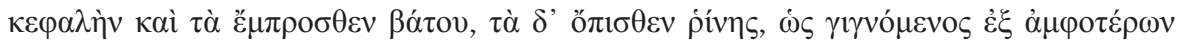

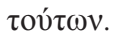

Among fish, none has been seen mating outside their species. But the rhine and the batos do seem to do this, for there is a fish called the rhinobatos, and it has the head and foreparts of a batos and the rear parts of a rhine, as though it were generated from both of these. ${ }^{43}$

Elsewhere he again shows this same qualified confidence: $\dot{\varepsilon} \pi \grave{i} \delta \dot{\varepsilon} \tau \tilde{\omega} v \quad \theta \alpha \lambda \alpha \tau \tau i ́ \omega v$ oủ $\theta \dot{\varepsilon} v$

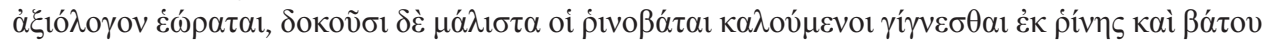
$\sigma v v \delta v \alpha \zeta o \mu \varepsilon v \omega \omega v$, "concerning marine animals, nothing worth reporting has been observed, but the so-called rhinobatos very much seems to be produced by the mating of the rhine with the batos." ${ }^{44}$ In both cases he signals that he is pretty sure that this fish is a hybrid, but he also clearly indicates that he is still one step removed from certainty. He has, it seems, not actually seen the two different species mating with each other, nor, one supposes, has a rhinobatos turned up in a pond that had previously contained only rhinai and batoi.

\section{DIFFICULT OBSERVATIONS}

There are a number of interesting passages where we seem to catch Aristotle in the middle of an as-yet-uncompleted research project. In describing how cuttlefish eggs develop, for example, he tells us that once the egg is laid there appears within it something like a hailstone (a phenomenon he has observed in the development of birds' eggs as well). ${ }^{45}$ This hailstone slowly transforms into the young cuttlefish, but Aristotle is not sure about how its umbili-

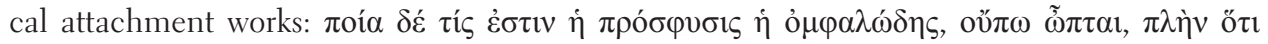

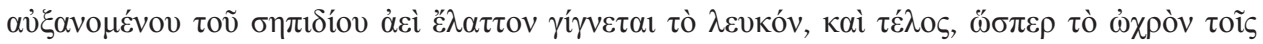

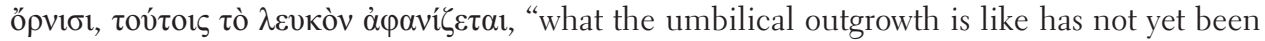
observed, but only that as the little cuttlefish grows the white always diminishes and in the end it disappears, just like the yolk does with birds." ${ }^{\prime 4}$ Assuming that these remarks reflect Aristotle's own observations, which I think is quite plausible in this instance, we see him here telling us both what he has managed to see and what he hopes one day to catch a glimpse of. He readily admits that he has not yet managed to see the umbilical outgrowth (perhaps he has never had a specimen at just the right stage of development).

On the contrary, Aristotle seems to think they are all female. On the hermaphroditism of some species of serranidae see Lavett C. Smith, "The Patterns of Sexuality and the Classification of Serranid Fishes," American Museum Novitates, 29 Jan. 1965 , pp. 120. For other passages on the erythrinus in Aristotle (expressing sometimes varying degrees of confidence) see Historia animalium 538a20-21, 567a27, and De generatione animalium 74la33-37, 760a8; for its habitat see Historia animalium $598 \mathrm{a} 13$.

${ }^{43}$ Historia animalium $566 \mathrm{a} 27 \mathrm{ff}$.

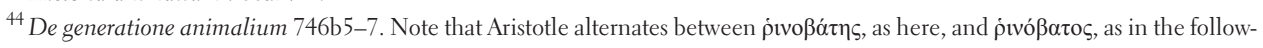
ing passage. To the best of my knowledge, only ṕvó $\beta \alpha \tau$ ç is attested outside of Aristotle, and even then it occurs only once, in a late ancient lexicon (Hesychius) where the term is defined as i $\chi \theta \tilde{v} \varsigma \pi$ otó $\varsigma$, "a kind of fish."

${ }^{45}$ Historia animalium 560a28. For hailstones in cuttlefish eggs see also Historia animalium $525 \mathrm{a} 7$.

${ }^{46}$ Historia animalium $550 \mathrm{a} 20 \mathrm{ff}$. 
Another observation that it is sorely tempting to ascribe to Aristotle himself-but that is, alas, unconfirmable-concerns the mating of wasps.

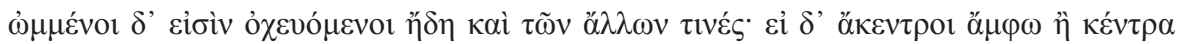

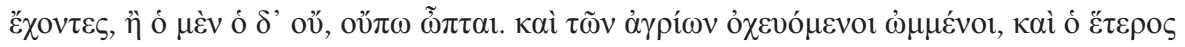

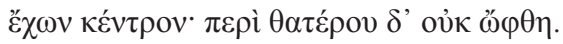

Some of the other [kind] have by now been observed mating, but whether both were stingless or had stingers, or one did and the other did not, has not yet been observed. Some wild wasps have been observed mating, and one had a stinger. But as for the other, it was not observed. ${ }^{47}$

Here there are a couple of indications that the observation of wild wasps mating was a one-off experience: the fact that only one of the mating pair was observed closely enough to determine whether it had a stinger has a very distinct ring of missed opportunity to it. Perhaps more telling, there is a shift in the grammatical structure, where the verbs of the first clauses (those

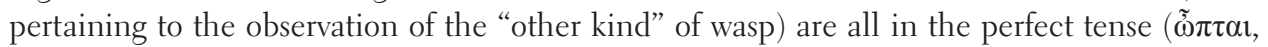
$\grave{\omega} \mu \mu \varepsilon \dot{v o t}$ ), and the point about whether one or both have stingers is worded as "[this] has not yet been observed." ${ }^{48}$ When he turns to the wild wasps, again we see a perfect participle (they "have ... been observed mating," in my translation); but when he comes to describe more particularly the observation of whether the latter wasps had stingers, he switches to the aorist tense when he tells us that one of the pair was not observed, dropping a hint that the attempted observation was a one-off experience. ${ }^{49}$

Whether it was Aristotle's own observation is impossible to determine definitively, but the passage does indicate a level of dedication on the part of the investigator, whoever that person might have been. For Aristotle says, twice, that wasps keep their stingers "on the inside," 50 meaning that he is likely limiting his class of wasps, $\sigma \varphi \tilde{\eta} \kappa \varepsilon \varsigma$, to what we now would call stinging wasps, rather than including our (distinct) class of parasitic wasps, which have their stinger-like ovipositors permanently on the outside (perhaps these fell under his third class of bee-like insects, the anthrenae $[\alpha v \theta \rho \tilde{\eta} v \alpha 1]) .{ }^{51}$ If he is limiting "wasps" to stinging wasps, then the investigator who tried to determine whether in this particular pair of mating wasps each of them had stingers would have had to interfere physically with the mating pair and, in fact, alarm them enough that they would produce their stingers (perhaps in their panic at being held by fingers or tweezers, perhaps being coerced actually to sting the observer). Whatever the case, we are told, the observer was unable on this one occasion to test both wasps, and the question must have been left for another day.

This observation of the wasps' mating contrasts nicely with a passage in the History of Animals where Aristotle is explaining that insects in general mate with the female pushing her "duct" ( $\pi$ ópos) up into the male from below:

\footnotetext{
${ }^{47}$ Historia animalium 628bl4-17.

${ }^{48}$ Compare De generatione animalium 76la8, where he says that another type of wasp has been seen mating "often," in spite of which fact, as he tells us at Historia animalium 629al, it is unclear whether they have stingers.

${ }^{49}$ If we compare this passage to others where he uses the singular aorist passive $\mathscr{\varphi} \theta \eta$, it is pretty clear that he often uses it to

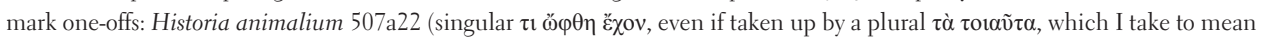

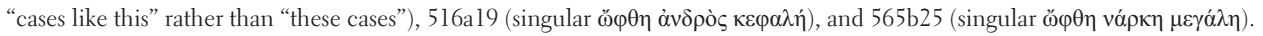

${ }^{50}$ Historia animalium 532al6; cf. De partibus animalium 683a9.

${ }^{51}$ I would like to thank James P. Pitts for his help with this section.
} 


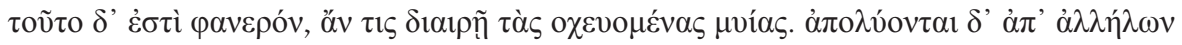

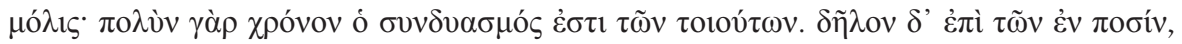
oĩov $\mu v i \tilde{\omega} v \tau \varepsilon \kappa \alpha i ̀ ~ \kappa \alpha v \theta \alpha \rho i ́ \delta \omega v$.

This becomes clear if one separates flies while they are mating. They come apart from each other with difficulty, for the coupling of insects like these takes a long time, which is clear in everyday insects such as flies and beetles. ${ }^{52}$

This experience is clearly of a different sort than the missed opportunity with the wasps. Anyone, $\tau \iota$, says Aristotle, can check this. The example is especially vivid because the animals from which we learn about this method of mating are around us all the time.

These claims that something remains to be seen are of a kind with other passages where he

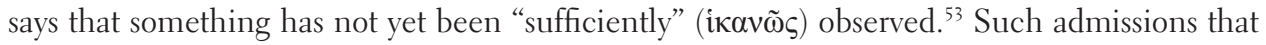
more work needs doing are littered throughout the biological corpus, and Aristotle is clearly not shy about using them..$^{54}$ "Not yet sufficiently seen" contrasts nicely with other passages where Aristotle tells us the opposite: that a thing has been seen sufficiently to be reliable. ${ }^{55}$

From a philosophical point of view, perhaps the most interesting and detailed expansion of the claim of insufficient observation comes in his discussion of bees, where Aristotle seems almost to be working out his theory in real time as the text progresses, weighing and thinking through each possibility and problem before the reader's very eyes.

He begins his discussion of bees in the Generation of Animals with a candid statement:

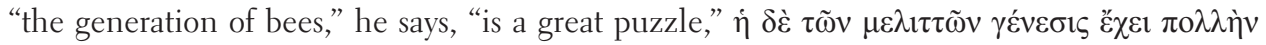
$\dot{\alpha} \pi$ opíav. ${ }^{56} \mathrm{He}$ then proceeds to think through all the many possibilities that may apply and outlines the pros and cons of each. The resulting list of possibilities, although very foreign to the modern eye, is at the same time admirably well thought through. Perhaps, he begins, bees collect their young from plants and flowers, the larvae being either spontaneously generated or else laid there by some other insect. ${ }^{57}$ Perhaps bees generate the young themselves (but then he has to weigh the evidence for how this would work when there is, uniquely, a threefold division within the species - kings, ${ }^{58}$ workers, and drones - instead of the usual two sexes). Perhaps the drones are generated by other insects, or generated spontaneously somewhere outside the hive, and the workers collect them from wherever they are found, while the kings and workers mate to reproduce their own kinds (a theory he says "some" hold). Perhaps the kings (or the workers, or the drones) alone reproduce themselves without mating and the other two kinds mate with each other. Perhaps each kind reproduces its own somehow. And for each of these last three theories, where some or all of the kinds reproduce their own, he then needs to decide whether this is by mating with another of the three kinds, mating with their own kind, or without mating at all.

Against the collecting-from-elsewhere theories, he argues, first, that this would mean that we should find bee larvae not-yet-collected and out in the wild, which we don't, and, second,

\footnotetext{
${ }^{52}$ Historia animalium $542 \mathrm{a} 6 \mathrm{ff}$.

${ }^{53}$ E.g., De generatione animalium 757b23, 760b30, 762a35.

${ }^{54}$ See Geoffrey E. R. Lloyd, The Revolutions of Wisdom (Berkeley: Univ. California Press, 1987), p. 141.

${ }^{55}$ E.g., Historia animalium 559b22; and De generatione animalium 723b19, 750b27, 751a12, 764a34.

${ }^{56}$ De generatione animalium 759a8. For this whole section, compare Historia animalium $553 \mathrm{al} 7 \mathrm{ff}$.

${ }^{57}$ Augustine would later hold this theory: et certe apes semina filiorum non coeundo concipiunt sed tamquam sparsa per terras ore colligunt, "and of course bees do not get their offspring by mating, but instead collect them by mouth, spread, so to speak, about the countryside" (De trinitate 3.8.13).

${ }^{58}$ Because he thinks they have stingers, Aristotle thinks that what we call queen bees are in fact male.
} 
that if these larvae were left there by some other animal, they would need to turn into that animal rather than into bees. And, relatedly, he then cites a law that no animal cares for offspring that does not appear to be oikeĩov, proper, to it. ${ }^{59}$ Against workers and drones mating with each other, he finds himself unable to see how one of them could be male and the other female: workers can't be female and drones male because the workers have stingers, and no other species of animal has "defensive weapons" assigned only to its females. But the workers can't be male either, because they care for their young and - we're about to learn something about ancient Greek parenting styles - no males make a habit of caring for their young. Against the theory that one or the other class of bee mates with its own kind, he points out that there does not seem to be any sexual difference between worker and worker that would make this possible - and also that workers do not seem to be produced unless the kings are in the hive (but drones, puzzlingly, do seem to be produced in the absence of kings, he says). ${ }^{60}$

He continues in this vein for several pages, deliberating over each of the very many possibilities in turn, before settling on what he sees as the most likely scenario given the evidence: because drones can be produced even when neither the king nor other drones are present, drones must be produced by workers, without copulation, and this means that workers must have both male and female within themselves. ${ }^{61}$ (He says that this manner of reproduction "seems to correspond with" [ and channa but also pointing out that, unlike worker bees producing drones, even these odd fish do not generate something different from themselves, so the parallel is not perfect. ${ }^{62} \mathrm{Fi}$ nally, he concludes that workers themselves must be produced asexually by the kings, who also produce their own kind from time to time in the same way. As strange and unparalleled as this method of populating a species may be, Aristotle finds some solace in the fact that there is at least a kind of mathematical series at play, where kings generate two things (kings and workers), workers generate one (only drones), and drones generate nothing. ${ }^{63}$

At this point Aristotle may, if we are not careful, be read as being more confident than he really is. But no- he is about to tell us that there is still some important uncertainty surrounding bees. Little hints in this direction are easy to have missed along the way: he introduces both of his major conclusions as "the remaining (possibility)," $\lambda \varepsilon i ́ \varepsilon \varepsilon \tau \alpha$, rather than asserting their certainty more definitively. ${ }^{64}$ And toward the end of the discussion he throws in a little string

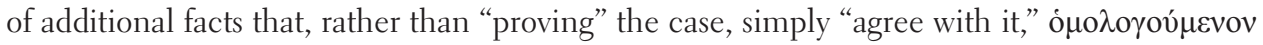
$\delta^{\prime} \dot{\varepsilon} \sigma \tau i^{65}{ }^{65}$ But it is when he comes to wrap up the section on bees that Aristotle becomes much more candid and reflective. He ends his discussion with one of the more remarkable methodological pronouncements in ancient science:

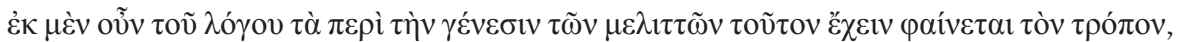

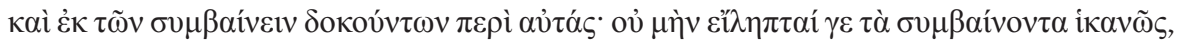

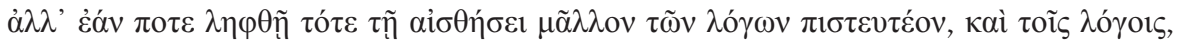

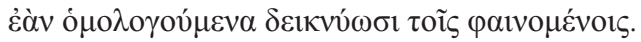

\footnotetext{
${ }^{59}$ De generatione animalium $759 \mathrm{bl}$.

${ }^{60}$ De generatione animalium $759 \mathrm{~b} 25$.

${ }^{61}$ De generatione animalium $759 \mathrm{~b} 30$.

${ }^{62}$ And note that this is the closest he ever comes to saying that the erythrinus and the channae are in any sense hermaphroditic. The fact that he twice pulls back from saying outright that these fish work exactly the same way as bees leads me to reject Peck's conclusion that Aristotle anticipated the discovery that sea perch are hermaphroditic. See Peck, Aristotle: History of Animals (cit. n. 33), commenting on Historia animalium 567a27.

${ }^{63}$ De generatione animalium $760 \mathrm{a} 12$.

${ }^{64}$ De generatione animalium 759b28, 760a4.

${ }^{65}$ De generatione animalium $760 \mathrm{~b} 16$.
} 
This, then, seems to be the state of affairs concerning the generation of bees, based on our reasoning and on the facts as they appear with respect to bees. But the facts have not been sufficiently established. If they ever are, then observation must be given more credence than reasoning, although reasoning, too, can be given credit if it be shown to agree with the phenomena. ${ }^{66}$

Now, "agreeing with the phenomena" often takes a broader meaning in Aristotle than just "agreeing with perception, ${ }^{167}$ but in this case Aristotle makes the primacy of sensory evidence

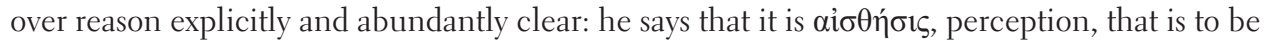
primary, while reasoning is to be subject to the constraints of that evidence. We can see, in fact, that this is a very good description of Aristotle's methodology in the biological books, where he seems always attentive to just where the evidence is pushing him and is quite happy to list exceptions to any of his general rules, should such exceptions appear.

That Aristotle is careful and deliberate about how he reports his certainty in the various types of observation claim seems by this point clear. More important, we see that he often signals his confidence in observation claims on a case-by-case basis, indicating to his reader not just how reliable he thinks testimony is in general but how reliable he thinks each particular instance of testimony - this animal, seen by this person in this way-might be. And of course testimony is only part of the story. I remarked at the outset of this essay that Aristotle is widely thought to have performed a number of his own observations, most strikingly in the study of animal anatomy, and his reports of observations, whether explicitly his own or simply unattributed, are clearly marked to signal the degree of trust he has in them. Whether assertions are stated as bare facts about the world and simply marked as "what is seen," or qualified with rhetorical formulas to signal his moderated certainty, Aristotle is very careful to maintain for his reader as much clarity as possible with regard to his own certainties and uncertainties, his own questions and puzzlements, and his own trusts and suspicions about individual observations.

\footnotetext{
${ }^{66}$ De generatione animalium $760 \mathrm{~b} 27-33$.

${ }^{67}$ Lloyd, Magic, Reason, and Experience (cit. n. 1), pp. 137-138.
} 